PRACE GEOGRAFICZNE

zeszyt $154,2018,7-33$

doi: $10.4467 / 20833113$ PG.18.010.9442

Instytut Geografii i Gospodarki Przestrzennej UJ

Wydawnictwo Uniwersytetu Jagiellońskiego

\title{
INICJATORZY I OPUSZCZENI: DEMOKRACJA LOKALNA PO GMINNYCH „ROZWODACH”
}

\author{
Pawet Swianiewič, Adam Gendঞ́witt, Julita Łukomska
}

\section{The initiators and the abandoned: local democracy after municipal "divorces"}

\begin{abstract}
The article analyzes 12 cases of municipal splits, which occurred in Poland in the early 1990s. The authors focus on the consequences for the local democracy visible in the data on electoral participation. The quasi-experimental analyses, in which the situation in the municipalities after splits is compared to the situation in the most-similar municipalities, demonstrates that the splits contributed to the increase of electoral turnout and supply of candidates in the local councils elections, but simultaneously limited the electoral competition, measured by the candidates-per-seat ratio. The analyses demonstrate the significant differences between the municipalities-initiators and municipalities which were "abandoned". The electoral mobilization effect, visible in the increased turnout rates, was significantly stronger among the initiators and this difference remains over a longer period. The results of the research based on the electoral data are supplemented by the analysis of the survey data documenting the opinions of two local communities, which experienced splits: Stoczek Łukowski (rural and urban municipalities), Raba Wyżna and Spytkowice.
\end{abstract}

Keywords: Poland, local government, territorial reform, municipal de-amalgamation, local democracy, local elections

\footnotetext{
${ }^{1}$ Artykuł przygotowany w ramach projektu „Reformy terytorialne w Europie - międzynarodowa perspektywa porównawcza" finansowanego ze środków Narodowego Centrum Nauki w ramach umowy nr 2017/26/M/HS5/00152.
} 
Zarys treści: Artykuł przedstawia analizę 12 przypadków podziałów gmin, które miały miejsce w Polsce w połowie lat 90. XX w. Autorzy skupiają się na konsekwencjach podziałów dla demokracji lokalnej, w szczególności - uczestnictwa wyborczego. Badanie w schemacie quasi-eksperymentalnym ( $\mathrm{w}$ którym sytuacja w gminach podzielonych jest porównywana z sytuacją w podobnych gminach, w których nie doszło do podziału), pokazuje, że podział gmin na mniejsze jednostki przyczynił się do wzrostu frekwencji wyborczej, wzrostu podaży kandydatów na radnych, ale również ograniczenia konkurencyjności wyborów, mierzonej liczbą kandydatów przypadających na 1 mandat. W większości przypadków ujawniły się również różnice między gminami-inicjatorami podziałów i gminami „opuszczonymi”. Efekt mobilizacji wyborczej, mierzony wzrostem poziomu frekwencji, był wyraźnie silniejszy w gminach-inicjatorach podziału i różnica ta utrzymuje się od wielu lat. Wnioski z badania opartego o dane wyborcze są uzupełnione analizą danych ankietowych dokumentujących opinie mieszkańców dwóch par gmin podzielonych: Stoczka Łukowskiego (gminy miejskiej i wiejskiej) oraz Raby Wyżnej i Spytkowic.

Stowa kluczowe: Polska, samorząd lokalny, reforma terytorialna, podział gminy, demokracja lokalna, wybory samorządowe

\section{Wprowadzenie}

Co najmniej od dekady badania i debaty wokół optymalnego rozmiaru jednostki samorządowej w swym wymiarze empirycznym koncentrują się na analizach zmian podziału terytorialnego (zob. np. Baldersheim i Rose 2010; Wollmann 2010, por. także przegląd literatury w Swianiewicz i in. 2016). Badanie reform terytorialnych zmieniających rozmiar jednostek samorządowych umożliwia - inaczej niż „statyczne” badania różnic pomiędzy jednostkami różnej wielkości - zidentyfikowanie relacji przyczynowych pomiędzy rozmiarem wspólnoty samorządowej (zwykle określanym liczbą mieszkańców) a różnymi wskaźnikami jej kondycji. Badania poświęcone skutkom zmian terytorialnych odnoszą się zazwyczaj do jednej z dwóch sfer zagadnień: wskaźników ekonomicznych albo wskaźników odnoszących się do funkcjonowania demokracji lokalnej. Dominują wyraźnie badania reform konsolidacyjnych (łączenia gmin) - taki jest bowiem dominujący kierunek reform samorządowych w większości opisywanych w literaturze krajów. W Polsce od lat 70. XX w. nie było znaczącej reformy terytorialnej na poziomie gminnym, natomiast wśród jednostkowych zmian dokonywanych w ostatnim dwudziestoleciu odnotujemy więcej przypadków podziałów niż łączenia gmin.

Celem niniejszego artykułu jest eksploracja obszaru stosunkowo słabo dotychczas zbadanego - wpływu podziałów terytorialnych na funkcjonowanie demokracji przedstawicielskiej na szczeblu lokalnym. Na przykładzie kilkunastu oddolnych podziałów gmin w Polsce, które miały miejsce w drugiej połowie lat 90. XX w. sprawdzamy, czy i w jakim stopniu podziały gmin (a więc zmniejszenie ich rozmiaru) wpłynęły na 
funkcjonowanie demokracji lokalnej, przede wszystkim - na wybory lokalne: podaż kandydatów i poziom frekwencji. Badamy przy tym różnice pomiędzy gminami-inicjatorami podziałów, a gminami „opuszczonymi” w wyniku podziału. Weryfikujemy empirycznie przypuszczenie, że reforma terytorialna przynosi odmienne skutki w każdej z tych grup.

Choć analizowane przez nas przypadki podziałów terytorialnych (w literaturze anglojęzycznej funkcjonuje również pojęcie „deamalgamacji” dla opisania tego procesu $^{2}$ ) są stosunkowo nieliczne, staramy się w naszych analizach zastosować rozumowanie quasi-eksperymentalne, pozwalające na trafniejszy opis skutków zmiany. Skokowa zmiana liczby mieszkańców w związku z przeprowadzoną reformą terytorialną pociąga za sobą skutki finansowe i społeczne - to wniosek jakościowo inny niż stwierdzenie różnic między mniejszymi a większymi gminami. W tym ostatnim przypadku łatwo bowiem narazić się na zarzut interpretowania pozornych związków przyczynowych. Trudno bowiem skontrolować wszystkie istotne czynniki niezależnie od wielkości gminy wpływające na obserwowane wymiary zróżnicowania - np. koncentrację ludności (ma ona wpływ na koszty jednostkowe wielu usług publicznych), zamożność (baza podatkowa oddziałuje na prowadzoną politykę fiskalną) czy cechy struktury społecznej lokalnej wspólnoty (mają wpływ na postawy i zachowania polityczne).

W przypadku analizy reform terytorialnych, zwłaszcza takich, które dotykają jednostek terytorialnych wybiórczo (tzn. część gmin podlega łączeniu, a część pozostaje we wcześniejszych granicach) zwykle stosuje się quasi-eksperymentalne schematy badawcze, znane również z tzw. kontrfaktycznego podejścia do ewaluacji. W takim schemacie gminy poddane reformie (połączone lub podzielone) traktuje się jako grupę eksperymentalną, a gminy niedotknięte reformą - jako grupę kontrolną. Przykładów takich badań można znaleźć w literaturze z ostatnich lat sporo: w ten sposób opisywane były m.in. efekty duńskiej reformy z 2007 r. (np. Blom-Hansen i in. 2014; Kjær i in. 2010; Lassen i Serritzlew 2011), ale także reform fińskich (np. Moisio i Uuistalo 2013), niemieckich (np. Blesse i Baskaran 2016), szwedzkich (np. Hinnerich 2009), szwajcarskich (np. Steiner i Kaiser 2017) czy holenderskich (Allers i Geertsema 2015).

Taki rygorystyczny schemat badawczy wydaje się dużo bardziej przekonujący w kontekście identyfikacji mechanizmu przyczynowego, choć nie jest on pozbawiony wad. Badacze zwracają uwagę m.in. na problem nielosowego doboru gmin podlegających reformie czy endogeniczności pomiaru, omawiają tę kwestię bardziej szczegółowo m.in. Blom-Hansen i in. (2014). Rozważymy te problemy w dalszej części artykułu.

\footnotetext{
${ }^{2}$ Jedno z niewielu dostępnych w światowej literaturze akademickiej badań na ten temat odnosi się do podziału, stosunkowo niedługo wcześniej przymusowo połączonych, gmin w Australii (por. Drew, Dollery 2014; De Souza i in. 2015).
} 
W pierwszej kolejności omówimy koncepcje teoretyczne, które pozwalają na postawienie hipotez dotyczących wpływu wielkości jednostki samorządowej na funkcjonowanie lokalnej demokracji przedstawicielskiej. Omówimy również wyniki dotychczasowych badań w tym zakresie. Po sformułowaniu hipotez badawczych zaprezentujemy skrótowo dobór badanych przypadków podziałów gmin w Polsce, wykorzystane dane oraz metodę badania. Analizy ilościowe wyników wyborów samorządowych uzupełniamy interpretacją danych ankietowych z badań terenowych prowadzonych w Stoczku Łukowskim (powiat łukowski), Rabie Wyżnej i Spytkowicach (powiat nowotarski) oraz Jaśliskach i Dukli (powiat krośnieński).

\section{Podział gmin a demokracja lokalna - dotychczasowe studia i hipotezy do badań empirycznych}

Podział gminy oznacza w praktyce powstanie wyraźnie mniejszych jednostek samorządowych. Taka zmiana jest doskonałą okazją do badania, w jaki sposób wielkość wspólnoty politycznej wpływa na funkcjonowanie lokalnej demokracji przedstawicielskiej i na wybory jej władz. Dlaczego w ogóle należałoby się spodziewać związku pomiędzy wielkością wspólnoty samorządowej a wyborami jej władz? Ogólne stwierdzenie z klasycznej pracy Dahla i Tuftego Size and democracy (1973), że mały rozmiar wspólnot politycznych sprzyja legitymizacji poprzez uczestnictwo (input legitimacy), zasadniczo znajduje potwierdzenie w wielu badaniach empirycznych samorządów lokalnych (Denters i in. 2014). Małe wspólnoty są wysoko oceniane ze względu na bliskość obywateli i decydentów oraz wyższy poziom zaufania opartego o gęste sieci lokalnych relacji rodzinnych, towarzyskich i sąsiedzkich (Denters 2002). Z kolei duże wspólnoty dają sobie radę z większym zakresem kwestii publicznych, a dzięki specjalizacji w lokalnej administracji i ekonomicznym korzyściom skali mogą skuteczniej przekładać obywatelskie oczekiwania na rezultaty (Swianiewicz i in. 2016: rozdz. 4).

Większość badaczy uczestnictwa w wyborach lokalnych argumentuje w zgodzie z teorią wyboru społecznego, że w małej gminie jednostkowy głos „,więcej waży”, tzn. w większym stopniu może wpłynąć na ostateczny wynik wyborów (Owen, Grofman 1984; Denters 2002), a to przekłada się na większe poczucie sprawstwa i motywację do głosowania. Im mniejsza jednostka terytorialna, tym niższa norma przedstawicielstwa (czyli liczba mieszkańców przypadających na jeden mandat), ale również większe prawdopodobieństwo, że o przydziale mandatu rozstrzygnie pojedynczy głos. Poza tym, w wyborach odbywających się w mniejszej skali dużo bardziej prawdopodobna jest osobista znajomość kandydatów, co może być dodatkową zachętą do wzięcia udziału w głosowaniu.

Istotnie - w mniejszych gminach notowana jest zazwyczaj systematycznie wyższa frekwencja w wyborach lokalnych - przegląd badań potwierdzających tę zależność 
przedstawił ostatnio van Houwelingen (2017). Z obszernej metaanalizy różnych czynników wpływających na uczestnictwo wyborcze, którą przedstawili Cancela i Geys (2006), wynika, że rozmiar gminy jest jednym z najważniejszych kontekstowych predyktorów poziomu uczestnictwa wyborczego. Jest też wśród wskaźników najczęściej używanych przez badaczy budujących modele wyjaśniające. Wiadomo jednak, że relacja między rozmiarem gminy a frekwencją wyborczą ma różną intensywność w poszczególnych krajach, jak również, że może zmieniać się w czasie (Frandsen 2002).

O zależności rozmiaru gminy i frekwencji w wyborach lokalnych mówią również badania reform terytorialnych. Koch i Rochat (2017) przedstawili ostatnio dowody na to, że łączenie mniejszych gmin w Szwajcarii przełożyło się na spadek frekwencji wyborczej, szczególnie widoczny w mniejszych społecznościach i szczególnie wyraźny w pierwszym cyklu wyborczym po reformie. Horiuchi i in. (2015) identyfikują podobny efekt reformy terytorialnej w Japonii. Kraaykamp i in. (2001), badając łączenie gmin w Holandii, co prawda identyfikują spadek frekwencji w połączonych gminach, zwracają jednak uwagę na krótkoterminowy wpływ zmiany wielkości, a także na relatywnie niewielką skalę efektu w porównaniu z wielkością spadków frekwencji wyborczej w kolejnych wyborach lokalnych w całym kraju.

Innym wątkiem, zdecydowanie rzadziej podejmowanym w literaturze, jest kwestia podaży kandydatów i konkurencyjności wyborów lokalnych. W tym przypadku mały rozmiar jednostek zwykle nie sprzyja realizacji postulatu konkurencyjnych wyborów jako wyznacznika jakości demokracji. W najmniejszych gminach elity lokalne mogą być zbyt wąskie, by wystawić wystarczającą liczbę kandydatów, aby rywalizacja wyborcza miała sens. Niekonkurencyjne wybory stoją w sprzeczności z postulatami Schumpeterowskiej teorii demokracji, zgodnie z którą istotą procesu demokratycznego jest konkurencja o władzę.

Rallings i Thrasher (1999), opisując wybory lokalne w Anglii, podobnie jak Kjær (2007) badający wybory lokalne w Danii, zwracają uwagę na systematycznie niższy poziom konkurencyjności wyborów w mniejszych jednostkach terytorialnych. W tym samym kontekście argument o „kurczeniu się demokracji lokalnej w najmniejszych gminach” powtarza również Wollmann (2010: 260), opisując sytuację samorządów lokalnych w Niemczech. Ograniczona konkurencyjność w demokratycznych wyborach jest bardzo powszechna w krajach z dużą liczbą bardzo małych gmin, np. w Czechach (Kostelecky’ 2007; Ryšavý i Bernard 2013). Aż w jednej trzeciej czeskich gmin przynajmniej raz w ciągu czterech analizowanych cykli wyborczych (1994-2006) zdarzyło się, że liczba kandydatów na radnych była równa liczbie mandatów. Ryšavý i Bernard zwracają uwagę, że kombinacja niekonkurencyjnych wyborów z częstymi reelekcjami stawia pod znakiem zapytania wyborczą rozliczalność (accountability) radnych.

Warto zauważyć, że kwestia konkurencyjności wyborów i uczestnictwa wyborczego (,podażowej” i „popytowej” strony głosowania) są ze sobą mocno związane. 
Wiadomo, że niekonkurencyjne wybory sprzyjają niższej frekwencji wyborczej (Swianiewicz i in. 2016; Gendźwiłł i in. 2015).

Podsumowując, można w dużym skrócie stwierdzić, że dotychczasowe badania z różnych krajów wskazują dość konsekwentnie na istnienie negatywnego związku wielkości gmin z frekwencją w wyborach władz lokalnych (im większe gminy, tym niższa frekwencja), a jednocześnie na pozytywny związek wielkości gmin z podażą kandydatów i konkurencyjnością wyborów lokalnych.

W obliczu przedstawionej tu argumentacji istotne wydaje się pytanie o istnienie efektu mobilizacyjnego - ożywienia lokalnej demokracji przedstawicielskiej związanego z podziałem gmin. Studium przypadków podziałów wybranych gmin w Polsce pozwala na przetestowanie koncepcji teoretycznych z nieco odmiennej perspektywy w stosunku do większości istniejących badań. Istotne różnice dotyczą dwóch zagadnień.

Po pierwsze, dotychczas przedmiotem analiz były zazwyczaj badania skutków łączenia gmin, natomiast w naszym przypadku analiza dotyczy podziałów jednostek samorządu terytorialnego. Ta różnica ma istotne implikacje teoretyczne. Można zapytać, czy skutki podziałów są lustrzanym odbiciem skutków łączenia gmin. Pozytywna odpowiedź na to pytanie wzmacniałaby argument o wpływie skali (wielkości) na funkcjonowanie demokracji lokalnej. Natomiast brak symetrii wskazywałby, że obserwowane następstwa zmian terytorialnych mogą być np. skutkiem samego procesu reformy, a nie zmiany wielkości jednostki samorządowej.

Po drugie, większość analizowanych w ostatnim czasie reform terytorialnych była narzucana, a przynajmniej inspirowana przez rząd (nawet jeśli o szczegółowym przebiegu granic w jakimś stopniu decydowały władze samorządowe - jak to miało miejsce na przykład w Danii czy Finlandii). Natomiast badane podziały polskich gmin następowały w wyniku oddolnej inicjatywy grup dążących do powstania odrębnej jednostki samorządowej. Skoro tak, to stosunkowo łatwo można wskazać stronę, która była inicjatorem „rozwodu przestrzennego” oraz stronę „opuszczoną”. Należy zatem zapytać, czy skutki obserwowane w tej części dawnej gminy, która doprowadziła do zmiany, wyglądają inaczej niż w gminie „opuszczonej”. A nawet dokładniej - czy większy entuzjazm, który wynika z podziału gminy spełniającego oczekiwania inicjatorów, przekłada się na większe ożywienie demokracji lokalnej w społeczności inicjatorów niż „opuszczonych”. Pytań takich nie dawało się postawić w większości wcześniej prowadzonych badań skutków reform terytorialnych ${ }^{3}$. Warto zauważyć, że

\footnotetext{
${ }^{3}$ Wyjątkiem są tutaj przytaczane już w przypisie 1. badania australijskie (Drew, Dollery 2014; De Souza i in. 2015). Jednak nawet te badania nie zawierają pełnej analogii do naszych analiz prowadzonych w Polsce, gdzie - w odróżnieniu od przedmiotu tamtych badań - znaczna część przypadków podziałów nie da się sklasyfikować jako ponowny podział gmin wcześniej scalonych.
} 
zagadnienie to nie było także rozważane we wspomnianych wcześniej - należących do bardzo nielicznych studiów procesu podziału gmin - badaniach australijskich.

W niniejszym artykule stawiamy hipotezy, że:

H1. Doprowadzenie do podziału ǵminy w tej części, która o to zabiegała (w gminie-inicjatorze):

1. Wywołuje efekt w postaci ożywienia demokracji lokalnej;

2. Efekt ten dotyczy zarówno strony podażowej (zwiększenia liczby kandydatów i konkurencji wyborczej), jak i popytowej (wzrostu frekwencji wyborczej);

3. Efekt ten w gminach-inicjatorach jest znacząco większy niż w gminach „opuszczonych".

Hipoteza ta nawiązuje do omówionych wcześniej koncepcji teoretycznych dotyczących relacji między wielkością gminy i demokracją lokalną. Pozwalają one spodziewać się, że mobilizacja wyborcza jest większa w małych jednostkach samorządowych, a zatem że wzrasta po przeprowadzeniu podziału gminy i że owo ożywienie można dostrzec zarówno we wskaźnikach opisujących „podażową”, jak i „popytową” stronę procesu wyborczego.

Przypuszczamy jednak, że sama zmiana wielkości nie jest jedynym istotnym czynnikiem. Jako że analizowane podziały dokonywane były na skutek oddolnej inicjatywy, realizacja oczekiwań wyrażanych przez społeczność lokalną mogła wpłynąć na dodatkowo wyższy poziom zadowolenia, poczucie wpływu na lokalne sprawy publiczne i mobilizację wyborczą. Spodziewamy się zatem, że wzrost aktywności wyborczej powinien być szczególnie widoczny w gminach, które były inicjatorami podziałów. Natomiast w gminach „opuszczonych” oczekujemy znacznie łagodniejszych zmian. Trzeba tu jednak dodać, że rozróżnienie efektów skali oraz efektu inicjatywy podziału jest o tyle trudne, że w większości badanych przypadków gmina będąca inicjatorem „rozwodu” była znacząco mniejsza od gminy „opuszczanej”. Taka sytuacja miała miejsce w 9 spośród 12 opisywanych przypadków podziału, gdzie różnica wielkości mierzonej liczbą mieszkańców przekraczała 30\%.

H2. Opisany w pierwszej hipotezie efekt entuzjazmu jest stosunkowo krótkotrwały, zaznacza się wyraźnie w pierwszym cyklu wyborczym, a potem stopniowo wygasa.

Hipoteza druga wiąże się z tym, że oczekiwania rozbudzane przez inicjatorów podziału bywają często nadmiernie optymistyczne i w dłuższej perspektywie prowadzą do rozczarowania, które może przekładać się na apatię. Można ten proces porównać - przy zachowaniu stosownych proporcji - do początkowego entuzjazmu i następującego po nim rozczarowania transformacją systemową obserwowaną w krajach postkomunistycznych, w tym w Polsce (Zagórski 2001). Spadki frekwencji po „fundujących” (tzn. pierwszych demokratycznych) wyborach były notowane niemal we wszystkich krajach regionu (Kostadinova 2003). 


\section{Dane i metoda badania empirycznego}

Do zasadniczej części badania wybraliśmy przypadki podziałów gmin, które miały miejsce w okresie jednej kadencji samorządowej - pomiędzy 1994 r. a 1998 r. Dodatkowo ograniczamy się do tych gmin, które liczyły (przed podziałem) poniżej 20 tys. mieszkańców. Chodzi o to, by w naszej analizie zachowań wyborczych wyeliminować komplikujący interpretację wyników wpływ zmiany ordynacji wyborczej. W latach 1994-2010 w wyborach do rad gmin obowiązywała ordynacja większościowa w gminach mniejszych, zaś ordynacja proporcjonalna w gminach liczących więcej niż 20 tys. mieszkańców. Zmniejszenie rozmiaru gminy poniżej 20 tys. mieszkańców oznaczało więc fundamentalną zmianę systemu wyborczego.

Dodatkowa komplikacja odnosi się do faktu, że od 2002 r. - na skutek zmiany przepisów ordynacji wyborczej - zmniejszyła się liczba wybieranych radnych. I tak na przykład, o ile w wyborach przeprowadzanych w latach 90. w gminach liczących do 4 tys. mieszkańców liczba wybieranych radnych wynosiła 15, ale w gminach liczących 15-20 tys. mieszkańców wybierano już 24 przedstawicieli, to począwszy od 2002 r. liczba radnych we wszystkich gminach do 20 tys. mieszkańców wynosi 15. Drugą ważną zmianą było wprowadzenie w 2002 r. bezpośrednich wyborów burmistrzów gmin. Nasze analizy ułatwia jednak fakt, że w pierwszych wyborach po podziałach (1998 r.) obowiązywała niemal identyczna ordynacja wyborcza jak w ostatnich wyborach przed podziałem.

Analizowane przypadki (wraz z zaznaczeniem gmin inicjatorów i ,opuszczonych”) opisane są w tabeli 1.

W grupie gmin będących inicjatorami podziału można zauważyć przynajmniej dwie prawidłowości:

- Na ogół są one mniejsze od gmin „opuszczanych” (w 10 na 12 przypadków).

Przesłanką dążenia do „rozwodu” było często poczucie marginalizacji interesów, wzmacniane przez przegłosowywanie radnych reprezentujących mniejsze miejscowości przez większość reprezentującą centrum gminy;

- Stosunkowo często zdarza się, że miejscowości będące inicjatorem podziału były już dawniej siedzibami władz lokalnych, potem zlikwidowanymi w toku reform konsolidacji terytorialnej. Istniała więc tradycja odrębności, do której odwoływali się inicjatorzy podziału, a czasem nawet poczucie krzywdy związane z likwidacją dawnej gminy. W większości przypadków były to tradycje dość odległe w czasie, sięgające czasów przed II wojną światową i funkcjonowania gromadzkich rad narodowych przed reformą gminną przeprowadzoną w 1973 r. W niektórych przypadkach oddzielające się ośrodki gminne mają historyczne tradycje (utraconych później) praw miejskich, ale w kilku przypadkach tradycje samodzielnej jednostki administracyjnej były nieco bardziej współczesne, przekraczające horyzont reformy gminnej z pierwszej połowy lat 70. Tak było w przypadku gminy Skarżysko Kościelne i Ksawerów, Spytkowice i Jaśliska (wszystkie funkcjonowały 
Tab. 1. Liczba mieszkańców w nowo powstałych gminach

Table 1. Number of population in newly created local governments

\begin{tabular}{|c|c|c|c|c|}
\hline $\begin{array}{l}\text { Nazwa gminy } \\
\text { przed podziałem } \\
\text { Name of local } \\
\text { government } \\
\text { before the split }\end{array}$ & $\begin{array}{l}\text { Rok zmiany } \\
\text { Year of the } \\
\text { change }\end{array}$ & $\begin{array}{l}\text { Liczba mieszkańców } \\
\text { przed podziałem } \\
\text { (w tys.), w nawiasie } \\
\text { liczba wybieranych } \\
\text { radnych Population } \\
\text { number before the split } \\
\text { (in ,000), number of } \\
\text { elected councilors } \\
\text { in brackets }\end{array}$ & $\begin{array}{c}\text { Nazwy gmin } \\
\text { po podziale } \\
\text { Name of local } \\
\text { government after } \\
\text { the split }\end{array}$ & $\begin{array}{c}\text { Liczba mieszkańców po } \\
\text { podziale (w tys.), } \\
\text { w nawiasie liczba } \\
\text { radnych wybieranych } \\
\text { w } 1998 \text { r. }\left({ }^{*}\right) \\
\text { Population number after } \\
\text { the split (in ,000), } \\
\text { number of councilors } \\
\text { elected in } 1998 \text { in } \\
\text { brackets }\end{array}$ \\
\hline \multirow{2}{*}{ Żegocina } & \multirow{2}{*}{1995} & \multirow{2}{*}{$9,26(20)$} & Żegocina & $4,37(18)$ \\
\hline & & & Trzciana & $4,96(18)$ \\
\hline \multirow{2}{*}{ Piwniczna } & \multirow{2}{*}{1995} & \multirow{2}{*}{$13,28(22)$} & Piwniczna & $9,80(20)$ \\
\hline & & & Rytro & $3,63(15)$ \\
\hline \multirow{2}{*}{ Stare Babice } & \multirow{2}{*}{1995} & \multirow{2}{*}{$17,85(24)$} & Stare Babice & $10,92(22)$ \\
\hline & & & Izabelin & $7,32(20)$ \\
\hline \multirow{2}{*}{ Mirzec } & \multirow{2}{*}{1995} & \multirow{2}{*}{$12,99(22)$} & Mirzec & $7,79(20)$ \\
\hline & & & Skarżysko Kościelne & $5,32(18)$ \\
\hline \multirow{2}{*}{ Suchedniów } & \multirow{2}{*}{1995} & \multirow{2}{*}{$16,86(24)$} & Suchedniów & $11,56(22)$ \\
\hline & & & Łączna & $5,30(18)$ \\
\hline \multirow{2}{*}{ Korczyna } & \multirow{2}{*}{1995} & \multirow{2}{*}{$14,85(22)$} & Korczyna & $127(22)$ \\
\hline & & & Krościenko Wyżne & $4,71(18)$ \\
\hline \multirow{2}{*}{ Witkowo } & \multirow{2}{*}{1995} & \multirow{2}{*}{$15,90(24)$} & Witkowo & $1385(22)$ \\
\hline & & & Powidz & $2,13(15)$ \\
\hline \multirow{2}{*}{ Cielądz } & \multirow{2}{*}{1995} & \multirow{2}{*}{$6,47(18)$} & Cielądz & 4,43 (18) \\
\hline & & & Regnów & $1,97(15)$ \\
\hline \multirow{2}{*}{ Tymbark } & \multirow{2}{*}{1997} & \multirow{2}{*}{$10,78(22)$} & Tymbark & $5,65(18)$ \\
\hline & & & Słopnice & $5,48(18)$ \\
\hline \multirow{2}{*}{ Pabianice } & \multirow{2}{*}{1997} & \multirow{2}{*}{$12,01(22)$} & Pabianice & $5,27(18)$ \\
\hline & & & Ksawerów & $6,81(18)$ \\
\hline \multirow{2}{*}{ Raba Wyżna } & \multirow{2}{*}{1998} & \multirow{2}{*}{$16,75(24)$} & Raba Wyżna & $12,89(22)$ \\
\hline & & & Spytkowice & $3,94(15)$ \\
\hline \multirow{2}{*}{$\begin{array}{l}\text { Stoczek } \\
\text { Łukowski }\end{array}$} & & & Stoczek Łukowski (miasto) & $2,70(15)$ \\
\hline & 1998 & $11,66(22)$ & $\begin{array}{l}\text { Stoczek Łukowski } \\
\text { (gmina wiejska) }\end{array}$ & $8,94(20)$ \\
\hline
\end{tabular}

Uwaga: gminy, które były inicjatorem podziału wyróżnione są kursywą.

$(*)$ - we wszystkich wymienionych gminach liczba radnych wybieranych od 2002 r. wynosiła 15

Źródto: obliczenia własne na podstawie danych GUS (www.stat.gov.pl).

Source: own calculations on the basis of GUS data (www.stat.gov.pl). 
jako odrębne gminy do 1976 r., ta ostatnia nie została ostatecznie objęta naszym badaniem ze względu na późniejszy moment powstania i trudności z porównywalnością wyników, gmina Jaśliska była samodzielną gminą do 1976 r., a potem od 2010 r.). Jeszcze dłużej (bo aż do 1992 r.) jako odrębne jednostki administracyjne funkcjonowały miasto i gmina wiejska Stoczek Łukowski.

Stosunkowo mało precyzyjnie sformułowane „ożywienie” demokracji lokalnej, do którego odnoszą się postawione wcześniej hipotezy badawcze, staramy się dostrzec we wskaźnikach wyborczych (wybory lokalne uznajemy bowiem za ważny, wyrazisty element demokracji na szczeblu lokalnym). Odnosimy się przy tym zarówno do „popytowej”, jak i „podażowej” strony procesu wyborczego, zwracając uwagę na mobilizację wyborców, jak też mobilizację kandydatów (lokalnych elit politycznych). Efektów podziału gmin poszukujemy, śledząc trzy podstawowe wskaźniki:

- poziom frekwencji wyborczej (\%) w wyborach samorządowych;

- liczbę kandydatów zgłoszonych w wyborach do rady gminy;

- liczbę kandydatów przypadających na 1 miejsce w radzie (miara intensywności konkurencji wyborczej).

Potrzeba rozróżnienia skutków podziału w gminach „,inicjatorach” i „opuszczonych”, a także nielosowy charakter selekcji gmin, które uległy podziałom, nie pozwala na proste zastosowanie standardowego schematu analitycznego difference-in-differences, stosowanego w wielu studiach reform terytorialnych. W naszej analizie ilościowej stosujemy jednak podobne quasi-eksperymentalne rozumowanie, poszukując różnic między grupami poddanymi działaniu bodźca (gminy podzielone) a odpowiadającymi im grupami kontrolnymi. Przeciętne wartości interesujących nas trzech wskaźników badamy w czterech grupach:

- w grupie gmin-inicjatorów podziałów $(\mathrm{N}=12)$;

- w grupie gmin - „opuszczonych”, czyli pozostałych po oddzieleniu się inicjatorów $(\mathrm{N}=12)$;

- w grupie kontrolnej gmin podobnych do ,inicjatorów” ( $\mathrm{N}=32)$;

- w grupie kontrolnej gmin podobnych do „opuszczonych” ( $\mathrm{N}=36)$.

Założyliśmy, że grupy kontrolne będą składać się z gmin możliwie najbardziej podobnych swoimi charakterystykami do gmin powstałych po podziale, przy czym dla każdej gminy z dwóch grup „eksperymentalnych” (inicjatorów i „,opuszczonych”) założyliśmy, że dobierzemy po 3 najbardziej podobne gminy. W tym celu zastosowaliśmy metodę poszukiwania „najbliższych sąsiadów” ze względu na sześć kryteriów (zmiennych) mierzonych w roku pierwszych wyborów samorządowych po podziale:

(1) liczba mieszkańców w 1998 r. (czyli wielkość gminy w roku pierwszych wyborów samorządowych po podziale);

(2) gęstość zaludnienia (1998 r.);

(3) zamożność budżetu gminnego (mierzona dochodami budżetu pomniejszonymi o dotacje celowe per capita) (1998 r.); 
(4) frekwencja wyborcza (1998 r.);

(5) liczba okręgów wyborczych (1998 r.), przybliżająca strukturę terytorialną gminy;

(6) liczba kandydatów w wyborach do rady w przeliczeniu na jedno miejsce (1998 r.).

Miarą podobieństwa jest odległość Euklidesowa w abstrakcyjnej przestrzeni wielowymiarowej utworzonej przez wymienione wyżej kryteria podobieństwa. Dodatkowo wymagaliśmy, by jednostki zaliczone do grupy kontrolnej zlokalizowane były w tym samym regionie (NUTS-1) co odpowiadająca im gmina z grupy „eksperymentalnej”. Łączna wielkość każdej z dwóch grup kontrolnych powinna wynosić trzykrotność liczebności grup „eksperymentalnych”, czyli 36 gmin. Niemniej w przypadku jednej z grup kontrolnych usunęliśmy cztery przypadki powtarzających się gmin (będących „najbliższymi sąsiadami” więcej niż jednej gminy z grupy gmin-inicjatorów podziału), stąd jej liczebność spadła do 32 gmin.

Opisany wyżej dobór gmin do grup kontrolnych redukuje w pewnym stopniu problem nielosowego doboru gmin, które zostały podzielone. Grupy kontrolne nie zawierają bowiem wszystkich pozostałych (niepodzielonych) gmin, ale są skonstruowane w oparciu o podobieństwo jednostek obserwacji w kilku istotnych i uzasadnionych teoretycznie wymiarach.

W istocie konsekwencje podziału gmin śledzimy poprzez badanie dynamiki interesujących nas wskaźników w okresie po podziale, traktując za punkt odniesienia sytuację przed podziałem. W tym celu analizujemy wykresy, w których wartości przeciętne dla dwóch grup „eksperymentalnych” porównujemy z odpowiadającymi im wartościami przeciętnymi dla dwóch grup „kontrolnych”. Wartości trzech badanych zmiennych dla wszystkich gmin relatywizujemy do roku 1994, przyjmując, że wartość bazowa każdego ze wskaźników - poziom frekwencji wyborczej, liczba zgłoszonych kandydatów i liczba kandydatów przypadających na 1 mandat - w 1994 r. wynosiła 1. Zmiany wartości zrelatywizowanych wskaźników śledzimy w pięciu kolejnych cyklach wyborczych (1998 - pierwsze wybory po podziale, 2002, 2006, 2010 i 2014).

Problematyczne jest oczywiście wyznaczenie wartości wskaźników dla gmin podzielonych z okresu przed podziałem. Przyjęliśsmy upraszczające założenie, że w 1994 r. w obu częściach gminy podzielonej był ten sam poziom frekwencji wyborczej, a także taka sama liczba kandydatów przypadająca na 1 mandat. Ma to swoje empiryczne uzasadnienie, jeśli prześledzi się średnie wartości wskaźników wyliczone dla okręgów wyborczych w dwóch częściach gmin przed podziałem ${ }^{4}$.

\footnotetext{
${ }_{4}$ Takie przybliżone wyliczenie jest możliwe na podstawie danych PKW. Podział na okręgi wyborcze w części gminy będącej inicjatorem podziału i w części gminy będącej „opuszczoną” po podziale nie powstał na podstawie dokładnego określenia granic okręgów wyborczych, bo bazy danych PKW nie zawierają takich informacji. Podstawą kwalifikacji okręgów wyborczych było miejsce zamieszkania kandydatów ubiegających się o mandat w danym okręgu. To przybliżenie opieramy na założeniu, że w wyborach do rad gmin, zwłaszcza w mniejszych wspólnotach, podstawowym wzorcem jest wystawianie kandydatów lokalnych, zamieszkujących w miejscowościach danego okręgu wyborczego.
} 
Okręgi należące do tych grup nie różnią się między sobą w sposób istotny statystycznie poziomem frekwencji wyborczej - dla okręgów położonych na terenie części gminy inicjującej podział średnia frekwencja w 1994 r. wynosiła 36\%, a w pozostałych okręgach tych gmin 38,8\% (różnica ta nie była istotna statystycznie; $\mathrm{t}=-1,78$ p>0,05). Podobny jest wynik zróżnicowania liczby kandydatów przypadających na 1 mandat - w okręgach położonych na terenie części gmin inicjujących podział wynosiła ona w 1994 r. - 2,5, a w pozostałych okręgach wyborczych 2,75; także i ta różnica była nieistotna statystycznie $(\mathrm{t}=-1,74 ; \mathrm{p}>0,05)$. Z kolei bezwzględną liczbę kandydatów ubiegających się o mandat radnego w 1994 r. rozdzieliliśmy pomiędzy dwie części gmin podzielonych w proporcji odpowiadającej proporcji liczby ludności przed podziałem.

Ważnym uzupełnieniem modeli ilościowych opartych o dane wyborcze jest analiza dwóch przypadków „par rozwodowych”. Opieramy ją o wyniki badań ankietowych dotyczących poziomu zadowolenia mieszkańców z funkcjonowania samorządu i ze skutków podziału gmin. Zostały one przeprowadzone:

- w Stoczku Łukowskim (podział na gminę wiejską i miejską) w 2008 r.;

- w Rabie Wyżnej i Spytkowicach - w 2009 r. ${ }^{5}$

W przypadku Stoczka Łukowskiego o podział zabiegały przede wszystkim elity polityczne części miejskiej gminy miejsko-wiejskiej. Radni miejscy byli mniej liczni od wybieranych w okolicznych wsiach i czuli się często marginalizowani przez grupę radnych wiejskich. W rezultacie w mieszkańcach miasta narastało przekonanie, że większość środków na rozwój przeznaczana jest na część wiejską, a miasto jest coraz bardziej zaniedbane. Ówczesny burmistrz gminy był przeciwny podziałowi i zamówił ekspertyzę Agencji Rozwoju Komunalnego, która miała wykazać negatywne skutki ekonomiczne „rozwodu”. Kiedy inicjatorzy podziału odnieśli sukces (wspierani przez wpływowych polityków szczebla centralnego, powiązanych z SLD), burmistrz zrezygnował z kandydowania na kolejną kadencję.

W przypadku Raby Wyżnej inicjatorami „rozwodu” byli mieszkańcy Spytkowic, które w nieodległej przeszłości były już samodzielną gminą, przyłączoną później do Raby. W tym przypadku ważnym wątkiem było właśnie poczucie odrębności związanej z pamięcią o samodzielnej przeszłości. Istotne znaczenie odgrywały także warunki geograficzne - wieś Spytkowice była stosunkowo słabo skomunikowana z pozostałą częścią gminy, leży w (oddzielonej niewysokim grzbietem) sąsiedniej dolinie, a ze względu na położenie przy ważnej drodze krajowej łatwiej tam o połączenie transportowe z innymi gminami niż z ze stolicą gminy - wsią Raba Wyżna.

\footnotetext{
${ }^{5}$ Badania ankietowe przeprowadzone były przez grupę studentów Uniwersytetu Warszawskiego (kierunek: Gospodarka przestrzenna, na Wydziale Geografii i Studiów Regionalnych) pod kierunkiem Pawła Swianiewicza, Marty Derek i Julity Łukomskiej (Stoczek Łukowski) oraz pod kierunkiem Pawła Swianiewicza i Adama Gendźwiłła (Raba Wyżna i Spytkowice).
} 
Tab. 2. Próba mieszkańców objętych badaniem ankietowym

Table 2. Sample of respondents of the survey

\begin{tabular}{|l|c|c|}
\hline \multicolumn{1}{|c|}{ Nazwa gminy / Name of local government } & Rok badania / Year of the survey & N \\
\hline Stoczek Łukowski - miasto & 2008 & 62 \\
\hline Stoczek Łukowski - gmina wiejska & 2008 & 120 \\
\hline Raba Wyżna & 2009 & 152 \\
\hline Spytkowice & 2009 & 40 \\
\hline
\end{tabular}

Także i w tym przypadku podział wspierany był przez ważnych polityków szczebla krajowego (w tym przypadku związanych z AWS, a potem z $\mathrm{PiS}$ ).

Badania, w których mieszkańcy pytani byli o swoją subiektywną ocenę skutków reformy, przeprowadzone były zatem około 10 lat po „rozwodzie”. Ogólna liczba respondentów objętych badaniami wyniosła 374 (tab. 2). Dobór respondentów miał charakter kwotowy, zapewniając proporcjonalną reprezentację mieszkańców poszczególnych sołectw, a także zbliżone do całej populacji rozkłady płci i wieku respondentów.

\section{Wpływ podziału na wybory lokalne}

Jak widać na ryc. 1 - przygotowanej na podstawie danych dla 12 wskazanych w części metodycznej przypadków „rozwodów” gminnych - podaż kandydatów w kolejnych po podziale wyborach wzrosła szczególnie szybko w grupie gmin „inicjatorów”. Część zauważonej różnicy można przypisać różnicy wielkości - gminy, które zainicjowały podział były zazwyczaj mniejsze niż gminy „opuszczone”, w związku z tym również „popyt” na kandydatów do rady wzrósł w nich w większym stopniu, gdy mieszkańcy nowej gminy mogli samodzielnie obsadzić całą radę. Wielkość rady gminy (liczba mandatów) nie jest liniowo zależna od liczby mieszkańców, w związku z tym w mniejszych gminach liczba mieszkańców przypadających na jednego radnego jest $z$ reguły znacznie niższa. Przeciętnie w badanej przez nas grupie gmin-inicjatorów liczba radnych wybieranych w 1998 r. wzrosła (w porównaniu z rokiem 1994) ponad 2,2 razy, podczas gdy w grupie gmin „opuszczonych” - tylko 1,4 razy. Efekt, o którym tu mowa, utrzymał się (a nawet lekko wzmocnił) w kolejnych wyborach przeprowadzonych w 2002 r. Warto w tym miejscu przypomnieć, że na skutek wprowadzonych wtedy zmian legislacyjnych liczba radnych w 2002 r. została zmniejszona i we wszystkich analizowanych przypadkach została zrównana (od 2002 r. we wszystkich gminach liczących do 20 tys. mieszkańców wybiera się 15 radnych. 


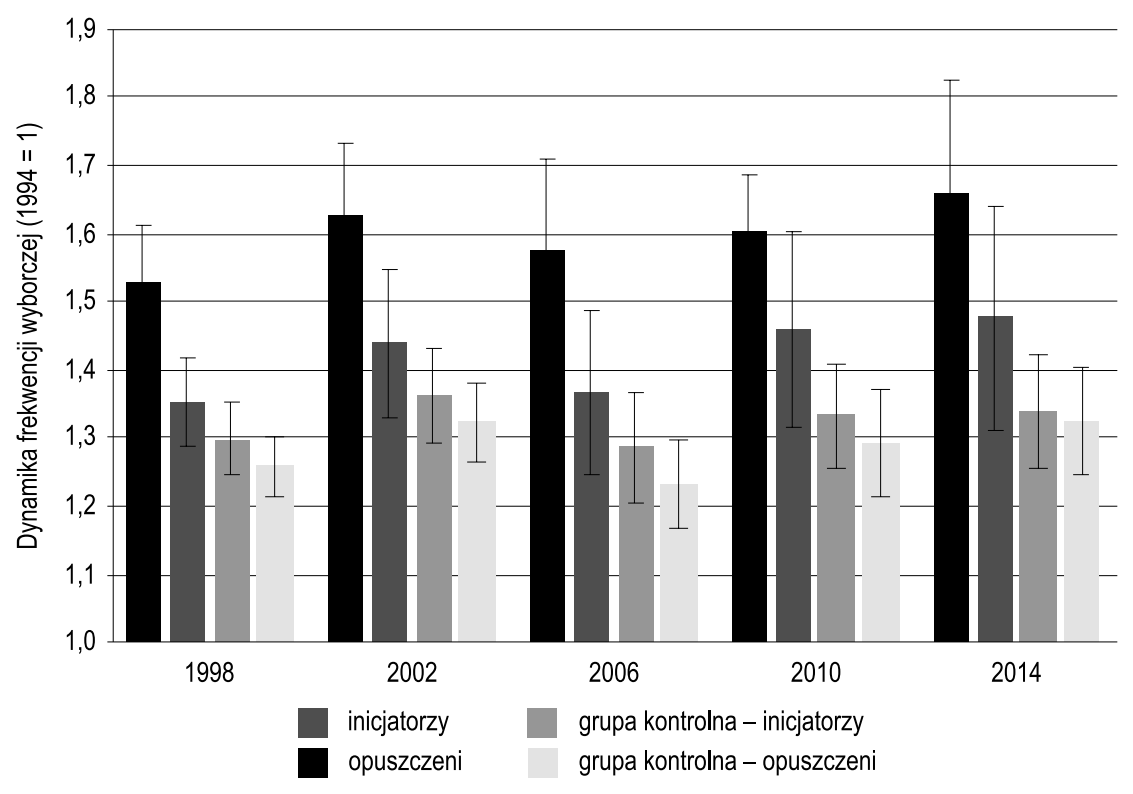

Ryc. 1. Zmiany liczby kandydatów ubiegających się o mandaty radnych w gminach powstałych w wyniku podziałów i gminach należących do grup kontrolnych

Fig. 1. Changes in number of candidates to municipal councils in local governments created after the split and in the control groups

Uwaga: słupki na wykresie ilustrują przeciętną zmianę w porównaniu z bazowym rokiem 1994 (ostatnie wybory przed podziałem). Na wykresie wskazano także $90 \%$ przedziały ufności średnich.

Źródto: obliczenia własne na podstawie danych PKW.

Source: own calculations on the basis of National Election Committee data.

Skoro w grupie gmin-inicjatorów najbardziej wzrosła liczba wybieranych radnych, można się było spodziewać, że spadek konkurencyjności będzie najbardziej widoczny właśnie w tej grupie - innymi słowy: nawet dodatkowa podaż kandydatów nie wystarczy do tego, żeby utrzymać konkurencyjność (mierzoną liczbą kandydatów na 1 mandat) na poziomie sprzed podziału. Jednak (jak widać na ryc. 2) zmiana w tym względzie była w grupie gmin-inicjatorów niemal identyczna jak w grupie gmin „opuszczonych”. Interpretujemy to jako potwierdzenie tezy o wyjątkowo wysokiej mobilizacji kandydatów w gminach, które były inicjatorami podziału. Równocześnie zauważamy, że w porównaniu z grupą kontrolną konkurencyjność wyborów do rady zmniejszyła się wyraźniej w gminach-inicjatorach (istotne różnice w 1998, 2002 i 2010) niż w gminach „opuszczonych”. 


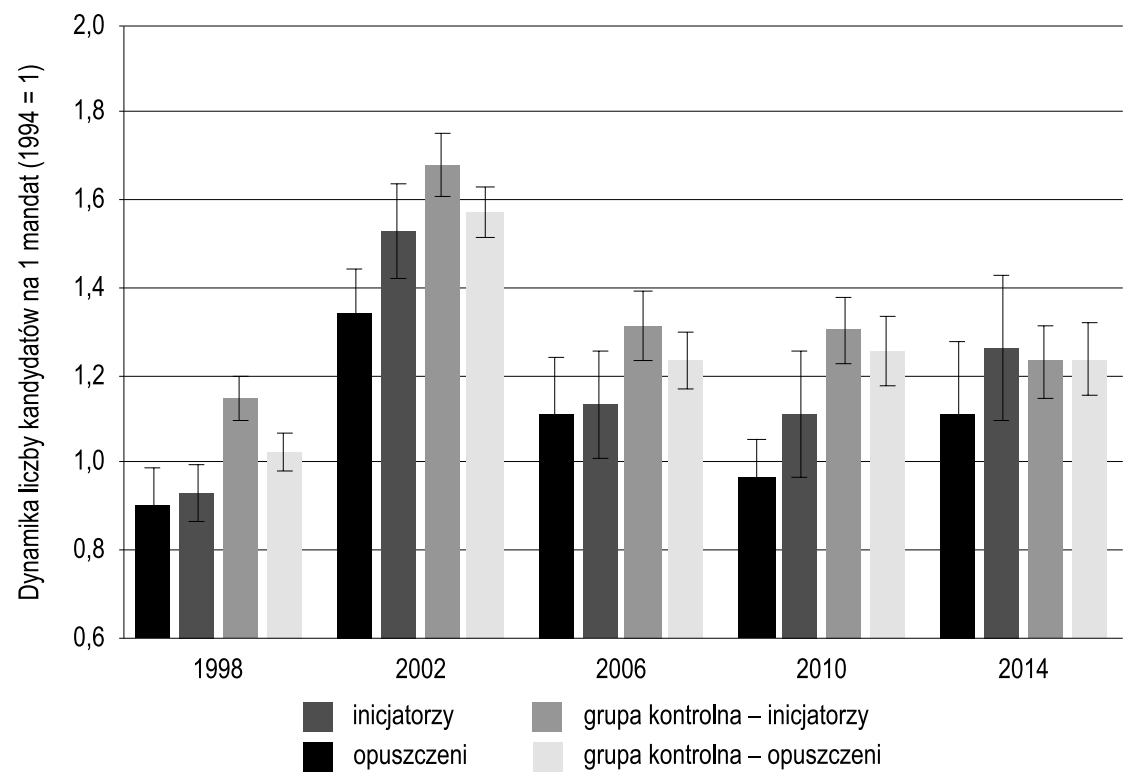

Ryc. 2. Zmiany konkurencyjności (liczby kandydatów przypadających na 1 mandat radnego) w gminach powstałych w wyniku podziałów i gminach należących do grup kontrolnych Fig. 2. Changes in competitiveness (number of candidates per 1 seat in the council) in split local governments and in the control groups

Uwaga: słupki na wykresie ilustrują przeciętną zmianę w porównaniu z bazowym rokiem 1994 (ostatnie wybory przed podziałem). Na wykresie wskazano także $90 \%$ przedziały ufności średnich.

Źródto: obliczenia własne na podstawie danych PKW.

Source: own calculations on the basis of National Election Committee data.

Wpływ podziału gminy na zachowania wyborcze widać także w analizie frekwencji wyborczej (ryc. 3). Tu również widoczna jest dysproporcja efektów między inicjatorami a „opuszczonymi”. Warto zauważyć, że w wyborach będących poziomem odniesienia (1994 r.) poziom frekwencji wyborczej w wyborach samorządowych był szczególnie niski, stąd we wszystkich grupach gmin w późniejszych latach frekwencja była wyraźnie wyższa względem owego poziomu odniesienia. Wzrost frekwencji w gminach „opuszczonych” był jednak niewiele większy (i nieistotny statystycznie) w porównaniu ze wzrostem frekwencji w odpowiadającej tym gminom grupie kontrolnej - po stronie „opuszczonych” trudno więc się dopatrzeć dodatkowej mobilizacji wyborców specyficznie związanej z podziałem gminy. W przypadku gmin-inicjatorów podziału różnica w stosunku do odpowiedniej grupy kontrolnej jest dużo bardziej znacząca i utrzymuje się w całym analizowanym okresie - przemawia to za „hipotezą 


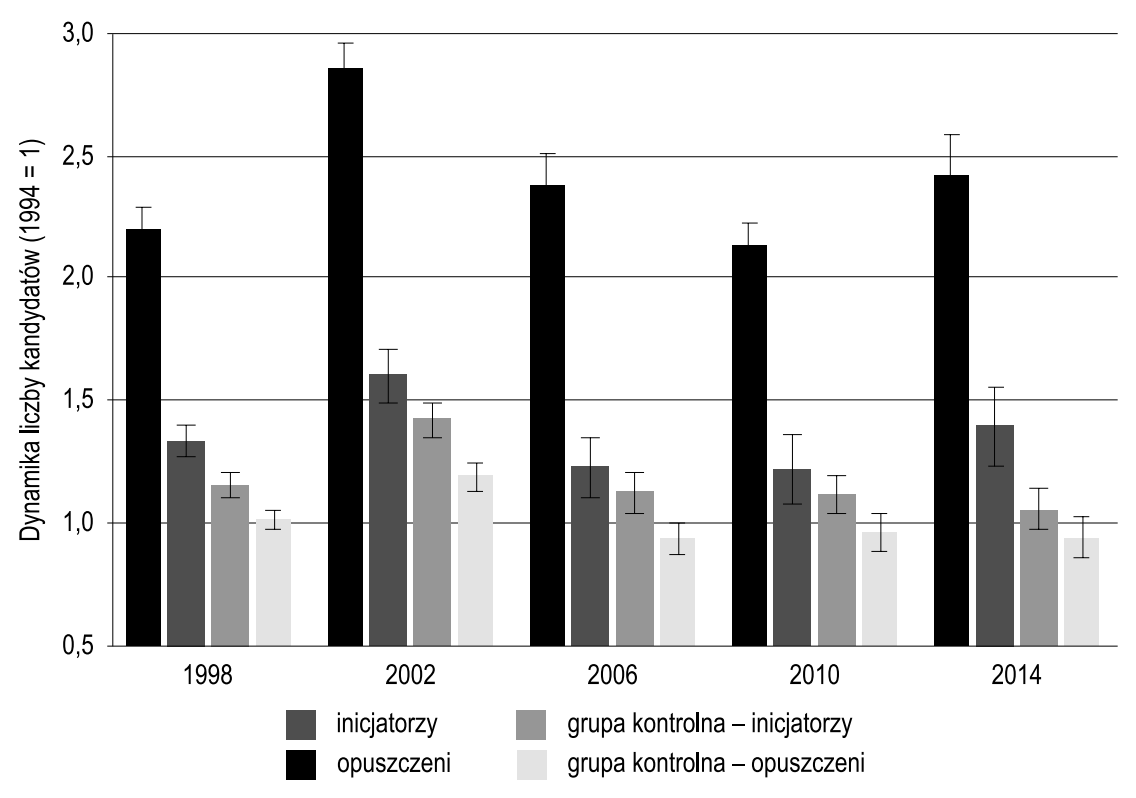

Ryc. 3. Zmiany poziomu frekwencji wyborczej w gminach powstałych w wyniku podziałów i gminach należących do grup kontrolnych

Fig. 3. Changes in turn-out in local elections in split local governments and in the control groups

Uwaga: słupki na wykresie ilustrują przeciętną zmianę w porównaniu z bazowym rokiem 1994 (ostatnie wybory przed podziałem). Na wykresie wskazano także $90 \%$ przedziały ufności średnich.

Źródto: obliczenia własne na podstawie danych PKW.

Source: own calculations on the basis of National Election Committee data.

dodatkowej mobilizacji”, tzn. uznaniem, że w gminach-inicjatorach wzrost poziomu frekwencji wyborczej jest związany właśnie z faktem podziału, a nie wyłącznie ze zmianą wielkości jednostki samorządowej.

Do tej pory nasze wyniki opierały się przede wszystkim na analizie wartości średnich dla wszystkich 12 par badanych gmin. Warto więc zapytać, jak częste były wyjątki od zaobserwowanych dla całego zbioru zależności. Dane w tabeli 3. wskazują, że efekt był najbardziej powszechny w pierwszych wyborach po podziale gmin (w 1998 r.). W wyborach kolejnych pojawia się coraz więcej odstępstw, co można z jednej strony tłumaczyć pojawianiem się znacznej ilości dodatkowych czynników zakłócających, których nie jesteśmy w stanie kontrolować naszym schematem quasi-eksperymentalnym, a z drugiej osłabieniem efektu nowości (czy też krótkotrwałego entuzjazmu) bezpośrednio po przeprowadzonej reformie. Zwraca też uwagę, 
Tab. 3. Liczba badanych gmin, w których różnica w stosunku do grupy kontrolnej była zgodna $\mathrm{z}$ tendencją obserwowaną przeciętnie $(\mathrm{N}=12)$

Table 3. Number of analysed municipalities in which difference from the control group was in the same direction as average $(\mathrm{N}=12)$

\begin{tabular}{|l|c|c|c|c|c|c|}
\cline { 2 - 6 } \multicolumn{1}{c}{} & \multicolumn{6}{c|}{ Rok wyborów/ Year of elections } \\
\cline { 2 - 7 } \multicolumn{2}{c|}{} & 1998 & 2002 & 2006 & 2010 & 2014 \\
\hline Liczba kandydatów w wyborach do rady / Number of candidates to local council \\
\hline Gminy - inicjatorzy / Municipalities - initiators & 11 & 6 & 6 & 7 & - \\
\hline Gminy "porzucone" / Abandoned municipalities & 10 & 7 & 6 & 8 & 7 \\
\hline Konkurencyjność - liczba kandydatów na 1 miejsce / Competitiveness - number of candidates per 1 seat \\
\hline Gminy - inicjatorzy / Municipalities - initiators & 12 & 11 & 10 & 10 & 7 \\
\hline Gminy "porzucone" / Abandoned municipalities & 9 & 8 & 8 & 8 & 7 \\
\hline Frekwencja w wyborach lokalnych / Turn-out in local elections & \multicolumn{2}{|c|}{7} \\
\hline Gminy - inicjatorzy / Municipalities - initiators & 10 & 10 & 8 & 8 & 9 \\
\hline Gminy "porzucone" / Abandoned municipalities & 9 & 7 & 9 & 9 & 7 \\
\hline
\end{tabular}

że odstępstwa od dominującej tendencji pojawiają się częściej wśród gmin „opuszczonych”, zaś stosunkowo rzadziej wśród gmin inicjatorów podziału.

Przytaczane w tej części wyniki potwierdzają więc różnice między gminami-inicjatorami i gminami „opuszczonymi”. Utrzymujące się różnice w zestawieniu z odpowiednimi grupami kontrolnymi sugerują, że nie chodzi tylko o efekt skali (związany z tym, że gminy-inicjatorzy są zazwyczaj mniejsze). W gminach, które doprowadziły do podziałów wyraźniejszy jest wzrost liczby kandydatów do rady i wzrost frekwencji wyborczej, co można wiązać ze szczególną mobilizacją społeczną następującą po odniesieniu sukcesu (doprowadzenia do pożądanego podziału). Równocześnie, wbrew oczekiwaniom, różnica ta nie wygasa po kilku latach (choć jej powszechność trochę się zmniejsza), trudno więc na podstawie analizowanych danych mówić o opisywanym w hipotezie drugiej efekcie rozczarowania skutkami reformy.

\section{Wyniki badania studiów przypadku: percepcja skutków podziału dekadę po reformie}

Badanie ankietowe przeprowadzone było około 10 lat po podziale gmin, można więc za jego pomocą zweryfikować postawioną w hipotezie drugiej tezę o zanikającym entuzjazmie i rozczarowaniu skutkami „rozwodu”. O ile większość mieszkańców gmin-inicjatorów przyznaje się do popierania podziału w chwili przeprowadzania 
konsultacji w tej sprawie, o tyle późniejsze ich opinie podlegały znaczącej ewolucji. W przeprowadzonym w 1995 r. w Stoczku Łukowskim referendum, przy frekwencji sięgającej 79\%, aż 83\% mieszkańców miasta opowiedziała się za podziałem (Swianiewicz 1996), ale już w ankiecie przeprowadzonej w 2008 r. do głosowania za podziałem przyznało się tylko niespełna dwa razy więcej mieszkańców niż przeciwko podziałowi (47\% respondentów zadeklarowało głosowanie w referendum „za”, a $26 \%$ „przeciw” podziałowi), zaś liczba zwolenników ponownego scalenia dwóch gmin zdecydowanie przewyższała liczbę przeciwników takiego pomysłu.

Natomiast w Spytkowicach wszyscy respondenci przyznający się do udziału w konsultacjach społecznych przed oddzieleniem gminy zadeklarowali, że opowiadali się za podziałem. Dziesięć lat później za utrzymaniem podziału była wprawdzie nadal zdecydowana większość mieszkańców, ale prawie $20 \%$ było zwolennikami ponownego połączenia z Rabą Wyżną.

Także analiza innych wyników badań przeprowadzonych w obu parach gmin wskazuje, że oba poddane obserwacji przypadki bardzo się od siebie różnią. W Stoczku Łukowskim mieszkańcy obu części podzielonej gminy są zgodni, że rozwód przyniósł bardziej pozytywne skutki dla gminy „opuszczonej” niż dla gminy-inicjatora (por. tab. 4). Co więcej, o takim zróżnicowaniu szczególnie mocno przeświadczeni są mieszkańcy gminy-inicjatora, wśród których przekonanych o przewadze skutków negatywnych dla własnej gminy jest więcej od tych, którzy dostrzegają głównie skutki pozytywne.

Subiektywna ocena skutków podziału gminy Raba Wyżna jest zupełnie inna. Mieszkańcy Spytkowic (gminy, która oddzieliła się do Raby Wyżnej) na ogół dostrzegają pozytywne skutki podziału dla swojej nowej jednostki, skutki negatywne dostrzegając głównie w odniesieniu do gminy „opuszczonej” (por. tab. 5).

Obserwacje te potwierdza analiza opinii dotyczących bardziej szczegółowych skutków podziału. W przypadku obu typów gmin (zarówno inicjatorów podziału, jak i „opuszczonych”) przeważają opinie o pozytywnym oddziaływaniu „rozwodu” na możliwość wpływu mieszkańców na podejmowanie decyzji przez władze samorządowe, jakość obsługi w urzędzie i poziom zainteresowania mieszkańców lokalnymi sprawami publicznymi (por. tab. 6 i 7). Opinie te potwierdzają więc tezy zawarte w koncepcjach teoretycznych przywoływanych w części wstępnej niniejszego artykułu. Ale z punktu widzenia prowadzonych przez nas analiz bardzo istotna jest obserwacja, że w Stoczku Łukowskim w każdym z analizowanych pytań ankietowych, a w przypadku pary gmin Raba Wyżna - Spytkowice w pytaniu o poziom zainteresowania mieszkańców, oceny mieszkańców gmin „opuszczonych” są bardziej optymistyczne niż opinie wyrażane przez mieszkańców gmin-inicjatorów.

W większości przypadków pozytywne są także opinie mieszkańców o skutku „rozwodu” dla intensywności konfliktów politycznych w gminach. Wydaje się to 
Tab. 4. Ogólna ocena skutków podziału gminy Stoczek Łukowski (w \%)

Table 4. General assessment of the consequences of the split of Stoczek Łukowski (in \%)

\begin{tabular}{|l|c|c|c|c|}
\cline { 2 - 5 } \multicolumn{1}{c|}{} & \multicolumn{2}{c|}{$\begin{array}{c}\text { Skutki dla gminy - inicjatora } \\
\text { Consequences for the initiating local } \\
\text { government }\end{array}$} & \multicolumn{2}{|c|}{$\begin{array}{c}\text { Skutki dla gminy „opuszczonej” } \\
\text { Consequences for the ,,abandoned” } \\
\text { local government }\end{array}$} \\
\cline { 2 - 5 } & $\begin{array}{c}\text { pozytywne } \\
\text { positive }\end{array}$ & $\begin{array}{c}\text { negatywne } \\
\text { negative }\end{array}$ & $\begin{array}{c}\text { pozytywne } \\
\text { positive }\end{array}$ & $\begin{array}{c}\text { negatywne } \\
\text { negative }\end{array}$ \\
\hline $\begin{array}{l}\text { Ocena mieszkańców } \\
\text { gminy-Inicjatora } \\
\text { Opinions of residents } \\
\text { from „initiating government” }\end{array}$ & 16 & 68 & 71 & 10 \\
\hline $\begin{array}{l}\text { Ocena mieszkańców } \\
\text { gminy „,opuszczonej” } \\
\text { Opinions of residents from } \\
\text { the „abandoned government” }\end{array}$ & 21 & 39 & 71 & 14 \\
\hline
\end{tabular}

Uwaga: liczby nie sumują się do $100 \%$, ponieważ pominięto odpowiedzi „nie mam zdania, trudno powiedzieć".

Źródto: badania ankietowe przeprowadzone w badanych gminach.

Source: survey in researched local governments.

Tab. 5. Ogólna ocena skutków podziału gminy Raba Wyżna (oddzielenie gminy Spytkowice, $\mathrm{w} \%)$

Table 5. General assessment of the consequences of the split of Raba Wyżna (split of Spytkowice, in \%)

\begin{tabular}{|l|c|c|c|c|}
\cline { 2 - 5 } \multicolumn{1}{c|}{} & \multicolumn{2}{|c|}{$\begin{array}{c}\text { Skutki dla gminy - inicjatora } \\
\text { Consequences for the initiating local } \\
\text { government }\end{array}$} & \multicolumn{2}{|c|}{$\begin{array}{c}\text { Skutki dla gminy ,opuszczonej” } \\
\text { Consequences for the ,,abandoned” } \\
\text { local government }\end{array}$} \\
\cline { 2 - 5 } \multicolumn{1}{c|}{} & $\begin{array}{c}\text { pozytywne } \\
\text { positive }\end{array}$ & $\begin{array}{c}\text { negatywne } \\
\text { negative }\end{array}$ & $\begin{array}{c}\text { pozytywne } \\
\text { positive }\end{array}$ & $\begin{array}{c}\text { negatywne } \\
\text { negative }\end{array}$ \\
\hline $\begin{array}{l}\text { Ocena mieszkańców } \\
\text { gminy-Inicjatora } \\
\text { Opinions of residents } \\
\text { from ,initiating government” }\end{array}$ & 68 & 20 & 34 & 29 \\
\hline $\begin{array}{l}\text { Ocena mieszkańców } \\
\text { gminy ,opuszczonej” } \\
\text { Opinions of residents from } \\
\text { the „,abandoned government” }\end{array}$ & 55 & 19 & 44 & 23 \\
\hline
\end{tabular}

Uwaga: liczby nie sumują się do $100 \%$, ponieważ pominięto odpowiedzi „nie mam zdania, trudno powiedzieć".

Źródto: badania ankietowe przeprowadzone w badanych gminach.

Source: survey in researched local governments. 
Tab. 6. Szczegółowa ocena skutków podziału gminy Stoczek Łukowski (w \%) Table 6. Detail assessment of consequences of split of Stoczek Łukowski (in \%)

\begin{tabular}{|l|c|c|c|c|}
\cline { 2 - 5 } \multicolumn{2}{l|}{} & \multicolumn{2}{c|}{$\begin{array}{c}\text { Wg inicjatorów } \\
\text { According to "initiators” }\end{array}$} & \multicolumn{2}{c|}{$\begin{array}{c}\text { Wg opuszczonych } \\
\text { According to ,abandoned” }\end{array}$} \\
\cline { 2 - 5 } & $\begin{array}{c}\text { pozytywne } \\
\text { positive }\end{array}$ & $\begin{array}{c}\text { negatywne } \\
\text { negative }\end{array}$ & $\begin{array}{c}\text { pozytywne } \\
\text { positive }\end{array}$ & $\begin{array}{c}\text { negatywne } \\
\text { negative }\end{array}$ \\
\hline $\begin{array}{l}\text { Wpływ mieszkańców na decyzje } \\
\text { Impact of citizens on decision making }\end{array}$ & 25 & 14 & 39 & 5 \\
\hline $\begin{array}{l}\text { Jakość obsługi w urzędzie } \\
\text { Quality of service in the town hall }\end{array}$ & 25 & 8 & 52 & 6 \\
\hline Zainteresowanie mieszkańców / Interest of citizens & 21 & 14 & 28 & 3 \\
\hline Koszty - inicjatorzy / Costs - initiators & 10 & 43 & 10 & 21 \\
\hline Koszty - opuszczeni / Costs - abandoned & 19 & 16 & 22 & 15 \\
\hline Konflikty - inicjatorzy / Conflicts - initiators & 10 & 22 & 10 & 7 \\
\hline Konflikty - opuszczeni / Conflicts - abandoned & 14 & 10 & 21 & 3 \\
\hline Inwestycje - inicjatorzy / Investments - initiators & 21 & 38 & 19 & 17 \\
\hline Inwestycje - opuszczeni / Investments - abandoned & 73 & 2 & 67 & 6 \\
\hline
\end{tabular}

Uwaga: liczby nie sumują się do $100 \%$, ponieważ pominięto odpowiedzi „nie mam zdania, trudno powiedzieć".

Źródto: badania ankietowe przeprowadzone w badanych gminach.

Source: survey in researched local governments.

logiczne - skoro nowe (mniejsze) gminy są bardziej homogeniczne pod względem tożsamości terytorialnych, to przypuszczalnie mniej jest powodów dla sporów wywołanych rozbieżnymi interesami. Niemniej, w naszych danych pojawia się jeden znaczący wyjątek. W mieście Stoczek Łukowski, będącym inicjatorem podziału gminy miejsko-wiejskiej, ogólne niezadowolenie ze skutków podziału przekłada się także na przekonanie o wzroście intensywności konfliktów w gminie po podziale (co ciekawe, zjawiska tego nie dostrzegają u swoich sąsiadów mieszkańcy gminy wiejskiej Stoczek Łukowski).

Zgodnie z koncepcjami teoretycznymi (odnoszącymi się do korzyści skali ujawniających się w wyniku reform terytorialnych) przeważają opinie o wzroście kosztów funkcjonowania samorządów po podziale. Ale mieszkańcy obu typów gmin są zgodni, że koszty te wzrosły bardziej w gminach-inicjatorach niż w gminach „opuszczonych”. Wyróżniają się też opinie odnoszące się do zmiany poziomu inwestycji. Wszyscy badani są zgodni co do tego, że poprawiło się finansowanie projektów rozwojowych w gminach „opuszczonych”. Natomiast w przypadku mieszkańców gmin-inicjatorów 
Tab. 7. Szczegółowa ocena skutków podziału gminy Raba Wyżna (w \%)

Table 7. Detail assessment of consequences of split of Raba Wyżna (in \%)

\begin{tabular}{|c|c|c|c|c|}
\hline & \multicolumn{2}{|c|}{$\begin{array}{l}\text { Wg inicjatorów } \\
\text { According to „initiators” }\end{array}$} & \multicolumn{2}{|c|}{$\begin{array}{l}\text { Wg opuszczonych } \\
\text { According to „abandoned” }\end{array}$} \\
\hline & $\begin{array}{l}\text { pozytywne } \\
\text { positive }\end{array}$ & $\begin{array}{l}\text { negatywne } \\
\text { negative }\end{array}$ & $\begin{array}{l}\text { pozytywne } \\
\text { positive }\end{array}$ & $\begin{array}{l}\text { negatywne } \\
\text { negative }\end{array}$ \\
\hline $\begin{array}{l}\text { Wpływ mieszkańców na decyzje } \\
\text { Impact of citizens on decision making }\end{array}$ & 53 & 13 & 40 & 16 \\
\hline $\begin{array}{l}\text { Jakość obsługi w urzędzie } \\
\text { Quality of service in the town hall }\end{array}$ & 50 & 8 & 45 & 5 \\
\hline Zainteresowanie mieszkańców / Interest of citizens & 48 & 15 & 34 & 7 \\
\hline Koszty - inicjatorzy / Costs - initiators & 10 & 45 & 11 & 30 \\
\hline Koszty - opuszczeni / Costs - abandoned & 10 & 18 & 24 & 30 \\
\hline Konflikty - inicjatorzy / Conflicts - initiators & 23 & 5 & 15 & 2 \\
\hline Konflikty - opuszczeni / Conflicts - abandoned & 18 & 3 & 26 & 11 \\
\hline Inwestycje - inicjatorzy / Investments - initiators & 43 & 28 & 43 & 8 \\
\hline Inwestycje - opuszczeni / Investments - abandoned & 45 & 0 & 81 & 8 \\
\hline
\end{tabular}

Uwaga: liczby nie sumują się do $100 \%$, ponieważ pominięto odpowiedzi „nie mam zdania, trudno powiedzieć".

Źródto: badania ankietowe przeprowadzone w badanych gminach.

Source: survey in researched local governments.

zdania są podzielone. W mieście Stoczek Łukowski przeważają opinie o zmniejszeniu strumienia inwestycji. Spadku takiego nie dostrzegają mieszkańcy drugiej gminy-inicjatora rozwodu (Spytkowic), ale także w tym przypadku odczucia odnoszące się do sytuacji w gminie-inicjatorze są bardziej pesymistyczne niż te dotyczące gminy „opuszczonej” (Raby Wyżnej). Wszystko to sugeruje, że w opinii mieszkańców skutki okazały się znacząco odmienne od zakładanych (i obiecywanych przez inicjatorów). Jeżeli pojawiły się korzyści, to odnosiły się one w większym stopniu nie do tych części gmin, które występowały z inicjatywą oderwania się, lecz do tych, które zostały „opuszczone”.

Dobrym podsumowaniem tej części badania są odpowiedzi na pytanie o poparcie dla inicjatywy ewentualnego ponownego scalenia rozwiedzionych gmin (por. tab. 8). Zwolennicy połączenia przeważają wśród mieszkańców miasta Stoczek Łukowski, a więc w gminie będącej inicjatorem podziału. Mieszkańcy gminy wiejskiej są raczej przeciwni ponownemu scaleniu gmin, ale warte zauważenia jest, że aż połowa respondentów nie ma w tej sprawie wyrobionego zdania. Jeśli chodzi o drugą 
Tab. 8. Czy byłbyś zwolennikiem ponownego scalenia gmin?

Table 8 . Would you support re-unification of split local governments?

\begin{tabular}{|l|c|c|c|c|}
\cline { 2 - 5 } \multicolumn{1}{c|}{} & \multicolumn{2}{c|}{ Stoczek Łukowski } & \multicolumn{2}{c|}{ Raba Wyżna - Spytkowice } \\
\cline { 2 - 5 } \multicolumn{1}{c|}{} & tak & nie & tak & nie \\
\hline $\begin{array}{l}\text { Mieszkańcy gmin inicjatorów } \\
\text { Residents of „initiating” local government }\end{array}$ & 60 & 18 & 18 & 69 \\
\hline $\begin{array}{l}\text { Mieszkańcy gmin „opuszczonych” } \\
\text { Residents of „abandoned” local government }\end{array}$ & 13 & 39 & 11 & 56 \\
\hline
\end{tabular}

Uwaga: liczby nie sumują się do $100 \%$, ponieważ pominięto odpowiedzi „nie mam zdania, trudno powiedzieć".

Źródto: badania ankietowe przeprowadzone w badanych gminach.

Source: survey in researched local governments.

analizowaną parę, to zarówno mieszkańcy Spytkowic, jak i gminy Raba Wyżna, są raczej przeciwni ponownemu połączeniu. Odsetek zwolenników ponownego scalenia jest jednak znacząco wyższy w Spytkowicach (prawie co piąty respondent) niż w „opuszczonej” gminie Raba Wyżna.

Wyniki są więc znacząco odmienne w obu badanych przypadkach. Ogólnie rzecz biorąc, opinie mieszkańców miasta Stoczek Łukowski (czyli pierwszej z analizowanych gmin-inicjatorów podziału) o skutkach podziału dla własnej gminy są dużo bardziej pesymistyczne od opinii wyrażanych przez mieszkańców Spytkowic (czyli drugiej z gmin-inicjatorów). Chociaż w przypadku kilku pytań także w Spytkowicach wyrażane ponad 10 lat po reformie opinie mieszkańców o podziale są nieco bardziej pesymistyczne od odpowiedzi udzielanych przez mieszkańców „opuszczonej” gminy Raba Wyżna. W sumie teza o zawiedzionych nadziejach i rozczarowaniu znajduje więc silne potwierdzenie w przypadku podziału gminy miejsko-wiejskiej Stoczek Łukowski i znacznie słabsze w przypadku oddzielenia gminy Spytkowice od Raby Wyżnej.

Pojawia się pytanie o wyjaśnienie przyczyn znaczącej różnicy między oboma przypadkami. Pełna odpowiedź na to pytanie wymagałaby dodatkowego pogłębionego badania o charakterze jakościowym, ale już teraz można wskazać na kilka czynników wpływających na tę odmienność.

Jedna z interpretacji odwołuje się do historii badanych obszarów. Spytkowice mają tradycje funkcjonowania jako odrębna gmina i to może wpływać na silne poczucie odrębności przekładające się na poczucie potrzeby własnego samorządu terytorialnego. Ale przecież podobny opis pasowałby do gminy wiejskiej i miasta Stoczek Łukowski. Obie te jednostki funkcjonowały w ramach jednego samorządu tylko kilka lat (w latach 90. XX w.). 
Druga z możliwych interpretacji sięga do charakterystyki geograficznej, a dokładniej do fizjografii terenu. Wieś Spytkowice położona jest w innej dolinie (oddzielonej od Raby Wyżnej niewysokim grzbietem), przy głównej drodze międzynarodowej. Połączenia drogowe między Spytkowicami i siedzibą gminy Raba Wyżna są mniej wygodne niż np. ze Spytkowic do pobliskiego miasta Rabka Zdrój. Ten czynnik, podobnie jak historia, wpływa na wyraźne poczucie odrębności, przekładające się na poczucie potrzeby własnego samorządu terytorialnego. Natomiast w gminie miejsko-wiejskiej Stoczek Łukowski nie było wyraźnych barier geograficznych, które mogłyby wpływać na poczucie odrębności. Co więcej, gmina wiejska ma obecnie siedzibę w mieście Stoczek Łukowski, które jest naturalnym centrum dla mieszkańców okolicznych wsi. Dążenie do podziału wynikało raczej z poczucia kulturowej odmienności miasta i wsi, a nie z ugruntowanych historycznie albo wzmacnianych położeniem geograficznym odrębności.

Trzecia możliwa interpretacja odwołuje się do teorii racjonalnego wyboru i wymiernych skutków finansowych podziału. Według tej interpretacji rozczarowanie podziałem z większym prawdopodobieństwem może pojawić się tam, gdzie obie części podzielonej gminy wyraźnie różnią się potencjałem ekonomicznym, a rozwód skutkuje poczuciem zubożenia gminy-inicjatora. Dla weryfikacji tej hipotezy spójrzmy na wysokość dochodów budżetowych badanych gmin bezpośrednio po podziale (w 1999 r.), a także na ewolucję zmian w ciągu kolejnych 10 lat (por. tab. 9). W przypadku Spytkowic i Raby Wyżnej minimalnie zamożniejsza była gmina - inicjator podziału, ale różnica potencjału (mierzonego dochodami w przeliczeniu na 1 mieszkańca) była stosunkowo niewielka - poniżej 10\%. Co ciekawe, po 10 latach sytuacja odwróciła się - to „opuszczona” gmina Raba Wyżna miała minimalnie wyższe dochody w przeliczeniu na 1 mieszkańca. Zakres tych zmian był na tyle nieduży,

Tab. 9. Dochody budżetu gminy w przeliczeniu na 1 mieszkańca (dochody w gminie-inicjatorze podziału, wyrażone jako \% dochodów w gminie „opuszczonej”)

Table 9. Local government budget revenues per capita (revenues in „initiating” local government as per cent of revenues in the „abandoned” local government)

\begin{tabular}{|l|c|c|}
\cline { 2 - 3 } \multicolumn{1}{c|}{} & 1999 & 2009 \\
\hline Stoczek Łukowski & 132 & 103 \\
\hline Spytkowice & 109 & 96 \\
\hline
\end{tabular}

Uwaga: pod uwagę wzięto dochody własne wraz z udziałami we wpływach z podatków PIT i CIT oraz subwencję ogólną. Pominięto natomiast mające charakter nieregularny dotacje celowe.

Źródto: obliczenia własne na podstawie sprawozdań budżetowych gmin.

Source: own calculations based on budget execution reports. 
że trudno spodziewać się by mógł wpływać na odczucia mieszkańców, niestudiujących na co dzień szczegółów polityki budżetowej.

Odmienną sytuację obserwujemy w gminie Stoczek Łukowski. Część miejska bezpośrednio po podziale miała zdecydowanie wyższe dochody, różnica wynosiła niemal jedną trzecią dochodów gminy wiejskiej. Tak duża dysproporcja potencjału utrzymywała się jeszcze przez kilka lat, ale w drugiej połowie pierwszej dekady XXI w. zaczęła się szybko zmniejszać i w 2009 r. wynosiła już tylko 3\%. Jeśli weźmiemy także pod uwagę fakt, że miasto Stoczek Łukowski jest znacznie mniejsze od gminy wiejskiej, można się zatem spodziewać, że przynajmniej w niektórych wydatkach zaznacza się tam zjawisko niekorzyści skali, zmiana mogła być odczuwana przez mieszkańców jako bardzo niekorzystna.

\section{Podsumowanie i wnioski}

Wyniki badań zachowań wyborczych w znacznym stopniu, choć nie całkowicie, potwierdzają obie nasze hipotezy. W przypadku zmian konkurencyjności i frekwencji w wyborach samorządowych efekt wywołany przez podział gmin był dość silny i miał spodziewany kierunek. W kwestii zmian konkurencyjności wyborów do rady efekt różnicy między gminami podzielonymi i ich grupami kontrolnymi dość szybko zanika, w kolejnych cyklach wyborczych robi się nieistotny statystycznie. Widać też wyraźne różnice w reakcji w gminach-inicjatorach i gminach „opuszczonych”. Na początku efekt „mobilizacyjny”, mierzony wzrostem frekwencji wyborczej, był wyraźnie silniejszy w gminach-inicjatorach podziału niż w gminach „opuszczonych”. Wbrew temu, czego się spodziewaliśmy w naszej hipotezie, różnica ta utrzymuje się przez wiele lat, a nie zanika (choć trochę słabnie) po wyczerpaniu „efektu nowości”. Hipoteza „efektu początkowego entuzjazmu” wynikającego z osiągnięcia zakładanego celu (powstania samodzielnej gminy), po którym następuje rozczarowanie brakiem osiągnięcia nierealistycznych oczekiwań, nie daje się zatem jednoznacznie potwierdzić. W wielu przypadkach mobilizacja społeczna będąca następstwem stworzenia nowej gminy okazuje się trwałym zjawiskiem. Ciekawa jest natomiast obserwacja, że z czasem przedziały ufności dla poszczególnych grup wyraźnie rozszerzają się, co sugeruje rosnące zróżnicowanie wewnątrz badanych grup. Reakcja w dłuższym okresie może więc przybierać odmienne formy w różnych podzielonych gminach, w zależności od zróżnicowanych innych warunków lokalnych, które pozostawały poza zakresem naszego badania.

Ten sposób rozumowania potwierdzają wyniki badań ankietowych w dwóch parach gmin podzielonych, przeprowadzone około 10 lat po „rozwodzie”. Tylko częściowo uzasadniają one tezę o zawiedzionych nadziejach i rozczarowaniu skutkami podziału gmin. $Z$ przeprowadzonych badań wynika, że po upływie dekady oceny 
skutków w gminach-inicjatorach są znacznie częściej negatywne niż w gminach „opuszczonych”. To rozczarowanie prowadzi także do częstszej niż w gminach „opuszczonych” akceptacji ewentualnego pomysłu ponownego scalenia gmin. Ta różnica między gminą-inicjatorem i gminą „opuszczoną” jest jednak bardzo wyraźna tylko w jednym z badanych przypadków. W drugiej analizowanej parze także się pojawia, ale jest dużo słabsza - w tym przypadku inicjatorzy podziału w znacznym stopniu nadal popierają ideę rozwodu. Różnice między obiema parami objętymi badaniem ankietowym mogą być wyjaśniane na dwa sposoby. Pierwszy z nich odwołuje się do charakterystyki geograficznej podzielonych gmin. W jednym przypadku (gdzie zjawisko wycofania poparcia dla idei rozwoju jest znacznie słabsze) mamy do czynienia z wyraźną odrębnością topograficzną i komunikacyjną nowo powstałej gminy. W drugim (gdzie poparcie dla ponownego scalenia jest silniejsze) mamy do czynienia z dwoma jednostkami wyraźnie powiązanymi funkcjonalnie i komunikacyjnie. Druga hipoteza oparta jest na paradygmacie racjonalnego wyboru i wskazuje na większy koszt ekonomiczny poniesiony przez gminę, w której po dekadzie samodzielnego funkcjonowania rozczarowanie skutkami podziału jest bardzo znaczne. Rozstrzygnięcie, która z wymienionych wyżej hipotez ma większą moc wyjaśniającą, wymagałoby dodatkowych studiów (obejmujących zapewne więcej przypadków podziału). Badania takie warto podjąć w niedalekiej przyszłości.

\section{Literatura}

Allers M.A., Geertsema J.B., 2016, The effects of local government amalgamation on public spending, taxation and service levels: evidence from 15 years of municipal consolidation, Journal of Regional Science, 56(4), 659-682.

Baldersheim H., Rose L. (red.), 2010, Territorial choice: The politics of boundaries and borders, London: Palgrave-Macmillan.

Blesse S., Baskaran T., 2016, Do municipal mergers reduce costs? Evidence from a German federal state, Regional Science and Urban Economics, 59, 54-74.

Blom-Hansen J., Houlberg K., Serritzlew S., 2014, Size, democracy, and the economic costs of running the political system, American Journal of Political Science, 58(4), 790-803.

Cancela J., Geys B., 2016, Explaining voter turnout: A meta-analysis of national and subnational elections, Electoral Studies, 42, 264-275.

Dahl R.A., Tufte E.E., 1973, Size and democracy, Stanford University Press, Stanford.

Denters B., 2002, Size and political trust: evidence from Denmark, the Netherlands, Norway and United Kingdom, Government \& Policy C: Environment and Planning, 20 (6), 793-812.

Denters B., Goldsmith M., Ladner A., Mouritzen P.E., Rose L.E., 2014, Size and local democracy, Edward Elgar, Cheltenham.

de Souza S.V., Dollery B.E., Kortt M.A., 2015, De-amalgamation in action: the Queensland experience, Public Management Review, 17(10), 1403-1424. 
Drew J., Dollery B., 2014, Separation anxiety: an empirical evaluation of the Australian Sunshine Coast Regional Council de-amalgamation, Public Money \& Management, 34(3), 213-220.

Frandsen A.G., 2002, Size and electoral participation in local elections, Environment and Planning C: Government and Policy, 20(6), 853-869.

Gendźwiłł A., Żółak T., Rutkowski J., 2015, Niekonkurencyjne wybory, brakujqcy kandydaci. Dlaczego niektóre komitety wyborcze nie wystawiajq kandydatów na burmistrzów??, Studia Regionalne i Lokalne, 4(62), 64-79.

Hinnerich B.T., 2009, Do merging local governments free ride on their counterparts when facing boundary reform?, Journal of Public Economics, 93(5-6), 721-728.

Horiuchi Y., Saito J., Yamada K., 2015, Removing boundaries, losing connections: electoral consequences of local government reform in Japan, Journal of East Asian Studies, 15(1), 99-125.

Kjær U., 2007, The decreasing number of candidates at Danish local elections: Local democracy in crisis?, Local Government Studies, 33(2), 195-213.

Kjær U., Hjelmar U., Olsen L.A., 2010, Municipal amalgamations and the democratic functioning of local councils: the case of the Danish 2007 structural reform, Local Government Studies, 36(4), 569-585.

Koch P., Rochat P.E., 2017, The effects of local government consolidation on turnout: Evidence from a quasi-experiment in Switzerland, Swiss Political Science Review, 23(3), 215-230.

Kostadinova T., 2003, Voter turnout dynamics in post-communist Europe, European Journal of Political Research, 42 (6), 741-59.

Kostelecky' T., 2007, Political parties and their role in local politics in the post-communist Cizech Republic, [w:] F. Lazin, M. Evans, V. Hoffmann-Martinot, H. Wollmann (red.), Local government reforms in countries in transition, Lexington Books, Lanham-Boulder-New YorkToronto-Plymouth, 121-139.

Kraaykamp M.G., van Dam M., Toonen T., 2001, Institutional change and political participation: The effects of municipal amalgamation on local electoral turnout in The Netherlands, Acta Politica, 36(4), 402-418.

Lassen D.D., Serritzlew S., 2011, Jurisdiction size and local democracy: Evidence on internal political efficacy from large-scale municipal reform, American Political Science Review, 105(2), 238-258.

Moisio A., Uusitalo R., 2013, The impact of municipal mergers on local public expenditures in Finland, Public Finance and Management, 13(3), 148.

Owen G., Grofman B., 1984, To vote or not to vote: the paradox of nonvoting, Public Choice, 42, 311-325.

Rallings C., Thrasher M., 1999, An audit of local democracy in Britain: the evidence from local elections, Parliamentary Affairs, 52(1), 58-76.

Ryšavý D., Bernard J., 2013, Size and local democracy: the case of Cæech municipal representatives, Local Government Studies, 39(6), 833-852.

Steiner, R., Kaiser, C., 2017, Effects of amalgamations: evidence from Swiss municipalities, Public Management Review, 19(2), 232-252. 
Swianiewicz P., 1996, Skutki ewentualnego podziatu miasta-gminy Stoczek Łukowski na dwie odrębne jednostki administracyjne, Agencja Rozwoju Komunalnego, Warszawa.

Swianiewicz P., Gendźwiłł A., Łukomska J., Kurniewicz A., 2016, Rozmiar gmin i powiatów a sprawność ich funkcjonowania. Wielkoludy i liliputy, Wyd. Naukowe Scholar, Warszawa.

van Houwelingen P., 2017, Political participation and municipal population size: A meta-study, Local Government Studies, 43(3), 408-428.

Wollmann H., 2010, Territorial consolidation reforms in German East Landers, [w:] P. Swianiewicz (red.), Territorial consolidation reforms in Europe, LGI-Open Society Institute, Budapest.

Zagórski K., 2001, Przemiany ocen sytuacji kraju w okresie transformacji, Gospodarka Narodowa, $3,48-60$.

Pawet Swianiewic:

Uniwersytet Warswawski

Wydziat Geografii i Studiów Regionalnych

ul. Krakowskie Prédmieście 26/28, 00-927 Warszawa

pswian@uw.edu.pl

Adam Gendæwwitt

Uniwersytet Wars:aweski

Wydziat Geografii i Studiów Regionalnych

ul. Krakowskie Præedmieście 26/28, 00-927 Warsะawa

a.gendwwill@uw.edu.pl

Julita Łukomska

Uniwersytet Warswawski

Wydziat Geografii i Studiów Regionalnych

ul. Krakowskie Præedmieście 26/28, 00-927 Warszawa

j.lukomska@uw.edu.pl 
